\title{
Community Participation within the Implementation of the Senior High School Equality Education Program in PKBM Cahaya
}

\author{
Elizon Nainggolan \\ Department of Educational Community \\ Universitas Negeri Medan, Indonesia \\ elizonnaingg06@gmail.com
}

Martini Dornauli Silitonga

Department of Educational Community

Universitas Negeri Medan, Indonesia

\author{
Sani Susanti \\ Department of Educational Community \\ Universitas Negeri Medan, Indonesia \\ susanti.sani@gmail.com
}

Mahfuzi Irwan

Department of Educational Community

Universitas Negeri Medan, Indonesia mahfuziirwan@gmail.com

\begin{abstract}
The problem in this study was that community participation in the implementation of the senior high school equality education program in PKBM Cahaya has not been optimal, how is the form of community participation in the implementation of the equality education program. This type of research used in this research is quantitative descriptive research that is identifying data in the effort to dissect the problem under study by describing the object of research based on research location research as it is by using frequency distribution calculations, and the percentage figures, data collection techniques using a questionnaire. The sample in this study was the community of Tanah Merah Village who participated in the senior high school equality education program at PKBM Cahaya Kota Binjai as many as 80 peoples. The results of the recapitulation study as a whole sample showed that community participation in the implementation of the Senior high school equality education program organized by PKBM Cahaya is still low, especially in the participation of ideas and labor participation, even if viewed partially, such participation is not necessarily negative because there are several sub-indicators that indicate high participation in supporting the equality program.
\end{abstract}

Keywords: community, equality program, pkbm, participation

\section{INTRODUCTION}

Indonesia has three types of education, one of which is non-formal education whose aim is to complement formal education. One of the programs of non-formal education is equality education. Equality education aims to provide opportunities for students from formal schools who have not been able to graduate, to be able to get a certificate by attending learning through an equality program [1][2], [3]. The equality program is also divided into three parts, for elementary schools the equality program is called Paket A, junior high schools are called Paket B, and senior high schools are called Paket C [2], [1] then, to organize the equality program used community learning centers, in Indonesia was called Pusat Kegiatan Belajar Masyarakat (PKBM) [3].

Not only as the organizer of the equality education program, the role of PKBM is also very important in overcoming the problems of education in Indonesia especially in the face of the industrial revolution era 4.0 which has many competency demands such as reducing illiteracy rates (Digital literacy, Human Literacy, and Technology Literacy), besides that learning in PKBM is preferred by adults because learning time at PKBM is more flexible compared to formal schools[4][5]. Of course, the implementation of this equality program requires participation from the community so that the program can run optimally because after all the characteristics of non-formal education are from society to society [6], [7], [8], [9]. Equality education is very much needed considering the purpose that is made to facilitate students in catching up with other students in terms of graduation / dropping out in formal schools, or to facilitate students to be able to go to school in accordance with the time they want, because one of the functions of equality education is to replace education formal [9], [2], [1].

Based on data from Ministry of Education and Culture of Indonesia 2016/2017 in North Sumatra that the number of students dropping out of school for the 4.075 elementary school, 2,284 junior high schools and 3,319 senior high schools. This figure shows the number of people dropping out of school is still quite a lot. This is an early sign that the Senior High School equality education program will run as expected in order to provide a solution to the problems of people who have dropped out of school.

The term participation is now the key in every community development program in various regions, this program becomes a new label that must be attached to every policy formulation and project proposal. In its development it is often spoken and written over and over again but it is not practiced, so it tends to lose the meaning of participation commensurate with the meaning of participation, participation, mutual learning process or understanding, mutual analysis, planning and action by a number of community members [10].

However, in every program that will be held by the community has a very important role because without the participation of the community, every program that will be carried out will be in vain [11], [12]. Like what is 
found in Tanah Merah Urban Village, Binjai City, there are still many people who drop out of school. Based on preliminary data in PKBM Cahaya in 2017 in Tanah Merah Urban Village, Binjai City, there were more than 180 consisting of 41 people participating in the Primary School Equality Program (Paket A), 59 people in Junior High School Equality Program (Paket B), and 80 people in Senior High School Equality Program (Paket C). Based on this fact, the implementation of non-formal education programs (Paket C) will run well.

However, community participation in the implementation of non-formal education programs is very necessary, because the success or failure of a program because it is very dependent on the size of community participation in development, with community participation or public participation, the planned program will achieve its objectives [13], [11], [14]. So, in this study the focus of research lies in how the level of community participation in the implementation of senior high school equality education programs in PKBM Cahaya.

\section{METHODS}

This research was conducted quantitatively using descriptive design. The research design provides procedures to be able to provide the information needed to compile or solve problems in research. Quantitative descriptive method is a research technique that aims to obtain a clear and systematic picture of data and facts in the field, then conduct an analysis of the problems found and then concluded [15]. The author chose quantitative descriptive because this approach is considered appropriate to see community participation in the implementation of the Senior high school equality education program in PKBM Cahaya, Tanah Merah Village, Binjai City.

Respondents in this study were citizens aged 15-32 years who dropped out of school and joined the Senior high school equality education program in Tanah Merah village as many as 80 people. Data collection instruments in this study used a questionnaire with data analysis techniques on the frequency of respondents' answers to the percentage, with the following formula [16]:

$$
\mathrm{P}=\frac{\boldsymbol{F}}{\boldsymbol{N}} \times 100 \%
$$

The variable measurement is based on the Likert scale:

$0 \%-25 \%$

$26 \%-50 \%$

$=$ Very Low

$51 \%-75 \%$

= Low

$76 \%-100 \%$

$=$ High

$=$ Very High

In this case the questionnaire used consisted of 30 items which were grouped into three parts which were part of the forms of community participation in the implementation of the Senior high school equality education program in PKBM Cahaya, namely the participation of ideas (contributing ideas, ideas, experiences owned by citizens learning for continuity of activities), power participation (various activities or participation in the form of efforts to repair or develop), participation in property (donating material in the form of money or providing facilities and infrastructure in the continuation of learning activities). Outlining the 30 questions consists of 4 choices of answers that are: very often (SS), Frequently (S), Sometimes (KK), and Never (TP) using a Likert scale calculation.

\section{RESULT ANDS DISCUSSION}

Generally, the success of the senior high school equality education program is largely determined by community participation. The situation in PKBM Cahaya Lingkungan II, Tanah Merah Urban Village, Binjai City, community participation in the implementation of equality education programs based on observations has not been optimal. Many factors cause this to be optimal even if there are also many positive things seen in the implementation of the equality program. So, there is the curiosity of the author / researcher to see the facts through this research.

This is evidenced by the results of research through a questionnaire distributed to people who participated in the senior high school equality program. Where the questionnaire contained a statement to find out how well community participation in the implementation of the Senior high school equality education program. In this research the forms of participation that will be seen are the participation of ideas, energy participation, and property participation. To find out how the Tanah Merah village community participating in the Senior high school Equality Education Program will be described as follows (Table 1).

Table 1

Data Analysis Results

\begin{tabular}{|c|c|c|c|c|c|c|}
\hline \multirow{2}{*}{ Variabel } & \multirow{2}{*}{ Sub Variabel } & \multicolumn{4}{|c|}{ Data analysis results (Percentage) } & \multirow{2}{*}{ Conclusion } \\
\hline & & SS & $s$ & KK & TP & \\
\hline \multirow{4}{*}{$\begin{array}{c}\text { Participation } \\
\text { of Ideas }\end{array}$} & 1. Program Planning & \multirow{4}{*}{$39 \%$} & \multirow{4}{*}{$45,75 \%$} & \multirow{4}{*}{$13,5 \%$} & \multirow{4}{*}{$2,12 \%$} & \multirow{4}{*}{ Low } \\
\hline & $\begin{array}{l}\text { 2. Program } \\
\text { Implementation }\end{array}$ & & & & & \\
\hline & 3. Utilization Program & & & & & \\
\hline & 4. Program Evaluation & & & & & \\
\hline \multicolumn{2}{|c|}{ Summary (Positive Participation) } & \multicolumn{4}{|c|}{$42,37 \%$} & \\
\hline \multirow{3}{*}{$\begin{array}{c}\text { Power } \\
\text { Participation }\end{array}$} & 1. Provide Information & \multirow[b]{3}{*}{$39,7 \%$} & \multirow[b]{3}{*}{$45,55 \%$} & \multirow[b]{3}{*}{$14,25 \%$} & \multirow[b]{3}{*}{$1,52 \%$} & \multirow[b]{3}{*}{ Low } \\
\hline & $\begin{array}{l}\text { 2. Actively involved in } \\
\text { organizing the } \\
\text { program }\end{array}$ & & & & & \\
\hline & $\begin{array}{l}\text { 3. Help the } \\
\text { tutor/manager in } \\
\text { organizing the } \\
\text { program }\end{array}$ & & & & & \\
\hline \multicolumn{2}{|c|}{ Summary (Positive Participation) } & \multicolumn{4}{|c|}{$42,62 \%$} & \\
\hline \multirow[t]{3}{*}{$\begin{array}{c}\text { Property } \\
\text { Participation }\end{array}$} & 1. Equipment & \multirow{3}{*}{$47 \%$} & \multirow{3}{*}{$52 \%$} & \multirow{3}{*}{$1 \%$} & \multirow{3}{*}{$0 \%$} & \multirow{3}{*}{ High } \\
\hline & 2. Material & & & & & \\
\hline & 3. Place & & & & & \\
\hline \multicolumn{2}{|c|}{ Summary (Positive Participation) } & \multicolumn{4}{|c|}{$43,97 \%$} & \\
\hline
\end{tabular}

So, based on the table above it can be seen that the level of community participation as a whole is still relatively low. That is because the distribution of opinions received through a questionnaire has many variations of answers. To find out how this can happen, it is worth looking at the following discussion.

\section{A. Participation of Ideas}

Participation of ideas is participation in the form of contributions of ideas, opinions or constructive thoughts, both in preparing student learning programs and to facilitate the implementation of the program by providing 
experience and knowledge to develop activities that are followed [17]. Participation given by the community can be seen from the participation or the community taking part in every program implementation both as students and as contributors of ideas or constructive ideas [8], [18].

Participation of ideas is community participation in contributing ideas or ideas in the formulation of Senior high school equality education program. Indicators of participation of these ideas consist of: (1) community participation in the formulation of learning; (2) the community's opinion that learning must be adjusted to the potential of the surrounding environment; (3) public opinion that learning must be adapted to the needs and abilities of learning citizens; and (4) the community's opinion that the program implementation must be adjusted to the time owned by the learning community.

So, based on the results of data analysis, the participation of the Tanah Merah community that participated in the senior high school equality education program in terms of ideas was considered low, because after tabulating the data the answers to the questionnaire regarding participation of ideas are more dominant categorized as good. However, after recapitulation of all sub-variables of participation, the results were at a percentage of $42.37 \%$ with the addition of positive participation options. The recapitulation results are formulated with a Likert scale. After being formulated with a Likert scale it can be concluded that community participation in terms of ideas is categorized as low because it is in the range of $26 \%-50 \%$.

Thus, the low level of participation in terms of ideas is an important note to improve so that the equality program runs optimally. However, the participation of ideas from the community is one of the most important aspects in the continuity of non-formal education programs specifically [9], [17]. Then the high level of community participation can have a positive impact on the development of Tanah Merah villages, because there is an influence of the level of community participation on village development [19], [20].

\section{B. Powers Participation}

Powers participation are participation given in the form of personnel for the implementation of businesses that can support the success of an equality education program of senior high school. Community participation in the form of energy provided by the community is the role of the community when participating in every activity carried out by educational institutions such as meetings [21], [13]. Indicators for staff participation include: (1) the community sharing information about equality education programs; (2) the community is actively involved in implementing the equality program; and (3) the community helps managers and tutors in organizing learning.

So, based on the results of data analysis, community participation in the implementation of the senior high school equality program in terms of more dominant power participation is categorized as good. However, after recapitulation of all sub-variables of labor participation, the results are at a percentage of $42.62 \%$ with the incorporation of positive participation options. The recapitulation results of labor participation are then formulated with a Likert scale. After being formulated with a Likert scale it can be concluded that the participation of the community of Tanah Merah village in terms of power participation is categorized as low because the value of $42.62 \%$ is in the range of $26 \%-50 \%$.

So, the low level of community participation in terms of power participation is interesting to discuss because based on the distribution of questionnaires, generally the community wants to participate in providing ideas, learning suggestions but is reluctant to be further involved in the learning process. This happens because the level of public understanding and awareness of the importance of participation in educational programs still tends to be low [19], moreover, participation in nonformal education programs which incidentally relies heavily on community volunteerism in carrying out its programs [12], [20]. In fact, the involvement of the Tanah Merah village community participating in the Senior high school program in the implementation phase will have a positive impact in the long term. Every community participation in the implementation of the senior high school equality education program can help the community in improving their lives to a better direction because the community itself will make decisions for its own progress [17].

\section{Property Participation}

Participation in the form of this material aims to collaborate with the organizer of the senior high school equality education program, tutors and managers of institutions to participate in the procurement of equipment, facilities and infrastructure to support learning. The indicators of this participation are related to community volunteerism in providing: (1) equipment; (2) material; and (3) place.

Based on the results of data analysis, community participation in the implementation of the senior high school equality program in terms of asset participation is more dominant as "good" categorized. Why it's being good? because most people want to help the implementation of the program by giving donations of places, materials and equipment, even though the donations are not evenly distributed to the community and the frequency is not the same between one person and someone else. In addition, the recapitulation results of the participation of the property are formulated with a Likert scale. After being formulated with a Likert scale it can be concluded that the participation of the red land community in the participation of property is considered high because $50.9 \%$ is in the range of $51 \%-75 \%$.

The participation of property is also very necessary in an activity, especially the Senior high school equality education program. Participation of the community of Tanah Merah village in terms of property is an interesting record because it can be one of the reasons why the equality program is still ongoing until now at the PKBM Cahaya. Even though the level of participation in other matters is still relatively low, it can be offset by the high level of community involvement in assisting the facilities or infrastructure of the equality program. So that the sustainability of the program can still be optimized. 
If referring Conyers within [22] concludes that success and failure in community participation are caused by two things. First, community awareness that their involvement can determine the final outcome of a plan. Second, the feeling that participation has a direct effect that can be felt. The community will not be interested in activities that are not in line with aspirations or that have no influence on the changing fate of the community.

Based on these explanations, it can be concluded that community participation in the implementation of the Senior high school equality education program that organized by PKBM Cahaya were still low, especially in the participation of ideas and labor participation, even if viewed partially, such participation is not necessarily negative because there are several sub-indicators that indicate high participation in supporting the equality program. While the participation of property, the majority of people in Tanah Merah participated high. The community tends to be able to sacrifice property such as tools, places, provide snacks and lend their garage to support the equality senior high school. However, on the other hand the community is reluctant to engage further such as thinking deeply about taking ideas, to being present at every meeting, which involvement can interfere with or consume their activities.

Thus, the willingness of the community to participate in organizing programs or activities that have been mutually agreed upon is an indication of initial capital from the community to develop independently [10], [14] Of course, this senior high school equality program requires maximum support from the community. Because the community are a partner of non-formal educational institutions such as the PKBM Cahaya. The support is in the form of participation. This research is very limited to the objects and sub-variables chosen because they only take three types of participation. Further and in-depth research is needed so that other levels of participation can be identified. Finally, through the results of this study, researchers will develop research that will focus on how to increase community participation in non-formal education programs in Indonesia. That way, community will be able to face the era of the industrial revolution 4.0 with all kinds of demands.

\section{CONCLUSIONS}

The participation of the Tanah Merah village community in the implementation of the Senior high school equality education program in the PKBM Cahaya are categorized as low, this has an impact on the learning process of the Senior high school in the PKBM Cahaya. The results of this study should be continued as a reference material for researchers to increase community participation in Tanah Merah village to participate in the implementation of non-formal education, especially senior high school, especially on the participation of ideas and energy.

\section{ACKNOWLEDGMENTS}

In this research, we would like to thank all the parties involved, namely: The organizer of PKBM Cahaya Ibu Sampe Tampubolon, Tanah Merah Community,
Binjai City, Medan State University Community Education Students who have helped us a lot in this research.

\section{REFERENCES}

[1] I. K. D. Hermawan, "the Performance of Equality Education As a Type of Non Formal," J. Pendidik. dan Kebud., vol. 18, no. September 2011, pp. 65-84, 2012.

[2] E. Nainggolan and M. Irwan, "Identification of NonEducation Tutors Difficulty In Education Process Of Learning Study Groups," J. Nonform. Educ., vol. 4, no. 2, pp. 161-168, 2018

[3] M. Irwan, "Evaluasi Program Pelatihan Pengolahan Limbah Kertas Semen pada Pusat Kegiatan Belajar Masyarakat ( PKBM ) Cahaya Kota Binjai Abstrak Kata Kunci : program , evaluasi , pelatihan , keterampilan , PKBM An evaluation of Cement Paper Waste Processing Training," J. Pendidik. dan Pemberdaya. Masy., vol. 4, no. 2, pp. 121-132, 2017.

[4] I. Ahmad, "Proses Pembelajaran Digital dalam Era Revolusi Industri 4 . 0 Era Disrupsi Teknologi," Kementeri. Riset, Teknol. dan Pendidik. Tinggi, pp. 1-13, 2018.

[5] A.- Irmawati, U. B. Wibowo, and A. D. Hastutiningsih, "Peran Pusat Kegiatan Belajar Masyarakat (Pkbm) Dalam Mengurangi Buta Aksara Di Kabupaten Karimun*)," J. Pendidik. dan Kebud., vol. 2, no. 1, p. 81, 2017.

[6] Unesco, Co stai sustainability of community learning centres : community ownership. Bangkok: U N E S C O Asia and Pacific Regional Bureau for Education, 2003.

[7] A. H. Pamungkas, "The Approaches Used by Community Learning Center (PKBM) to Achieve Sustainable Development Goals in Solok Selatan West Sumatra Province Indonesia," vol. 293, no. Nfeic 2018, pp. 14-18, 2019.

[8] R. Siri and O. S. Chantraprayoon, "Local community participatory learning with a nature interpretation system: A case study in Ban Pong, Sansai district, Chiang Mai, Thailand," Kasetsart J. Soc. Sci., vol. 38, no. 2, pp. 181185, 2017.

[9] P. Suwarno, "Equality in Education and Employment for Sustainable Development of Diverse Indonesia : Enhancing Equal Opportunity , Volunteerism , and Philanthropy," vol. 293, no. Nfeic 2018, pp. 1-8, 2019.

[10] M. Miessen, The nightmare of participation. Berlin: Sternberg Press, 2010

[11] A. van den Beemt, E. Ketelaar, I. Diepstraten, and M. de Laat, "Teachers' motives for learning in networks: costs, rewards and community interest," Educ. Res., vol. 60, no. 1, pp. 31-46, 2018.

[12] E. Purwanto, A. Aunnurahman, and W. Wahyudi, "Management of Equality Program Development in NonFormal Education Unit (SPNF) SKB of Kubu Raya District," JETL (Journal Educ. Teach. Learn., vol. 3, no. 2, p. 260, 2018.

[13] N. Novitasari, E. S. Redjeki, and Z. Nasution, "Strategi Membangun Masyarakat Gemar Belajar," J. Pendidik. Teor. Penelitian, dan Pengemb., vol. 3, no. 2, pp. 267-270, 2018.

[14] T. Pimoljinda and R. Siriprasertchok, "Failure of public participation for sustainable development: A case study of a NGO's development projects in Chonburi province," Kasetsart J. Soc. Sci., vol. 38, no. 3, pp. 331-336, 2017.

[15] J. W. Creswell, Research Design, III. California: SAGE Publication, 2014.

[16] A. Sudijono, Pengantar statistik pendidikan, I. Jakarta: Rajawali Pers, 2009. 
[17] F. Kamberi and B. Baliqi, "Participation of the Community in the Decision-Making process - Case the Municipality of Pristina," Path Sci., vol. 4, no. 8, pp. 5001-5012, 2018.

[18] A. Fahrudin, "Pemberdayaan Partisipasi dan Penguatan K." . Medan: Fokus.

[19] A. Mustanir, H. Dema, H. Syarifuddin, K. Meity, and S. Wulandari, "Pengaruh Motivasi dan Partisipasi Masyarakat terhadap Pembangunan di Kelurahan Lalebata Kecamatan Panca Rijang Kabupaten Sidenreng Rappang," J. Ilm. Clean Gov., vol. 2, no. 1, pp. 27-39, 2018.
[20] A. Uceng, A. Ali, A. Mustanir, and N. Nirmawati, "Analisis Tingkat Partisipasi Masyarakat Terhadap Pembangunan Sumber Daya Manusia Di Desa Cemba Kecamatan Enrekang Kabupaten Enrekang," J. MODERAT, vol. 5, no. 2, pp. 1-17, 2019.

[21] S. Xinke, "Participation Intention and Influencing Factors of Primary and Secondary School Teachers in the Network Training Community: Taking Jinhua City as an Example," vol. 334, no. Hsmet, pp. 186-193, 2019.

[22] K. Mulk, Menggugat Partisipasi Publik dalam Pemerintahan Daerah. Malang: Bayu Media Publishing, 2007. 